\title{
MORINGA (MORINGA OLEIFERA) LEAF NUTRITIONAL COMPOSITION AS INFLUENCED BY SOIL PHYSICAL AND CHEMICAL PROPERTIES AND TREE AGE UNDER DIVERSE AGRO-ECOLOGICAL CONDITIONS
}

\author{
BoPAPE-MABAPA, M. P. ${ }^{12^{*}}-$ AYISI, K. K. ${ }^{2}$ - MARIGA, I. K. ${ }^{1}$ - MASHAO, F. M. ${ }^{2}$ \\ ${ }^{1}$ University of Limpopo, Department of Plant Production, Soil Science and Agricultural \\ Engineering, Private Bag X1106, Sovenga 0727, Republic of South Africa \\ ${ }^{2}$ University of Limpopo, Risk and Vulnerability Science Centre, Private Bag X1106, Sovenga \\ 0727, Republic of South Africa \\ *Corresponding author \\ e-mail: paulina.mabapa@ul.ac.za; phone: +27-72-200-9692 \\ (Received $18^{\text {th }}$ Oct 2019; accepted $12^{\text {th }}$ Feb 2020)
}

\begin{abstract}
A study was carried out in the five districts of the Limpopo Province in South Africa to determine the influence of soil physical and chemical properties on the nutritional composition of moringa leaves. Soil samples under moringa canopy and $5 \mathrm{~m}$ away from the base of the trees as well as fresh leaf samples were collected from 31 moringa plantations in Limpopo Province during the summer season (November 2015 to January 2016). Soils at a depth of 0 to 30 and 30 to $60 \mathrm{~cm}$ were grouped according to textural classes and analyzed for physical and chemical properties. The harvested leaves were dried at room temperature and their nutritional compositions were determined. The study revealed improved soil nutritional composition under moringa trees, mainly in areas where the trees were more than three years old as compared to control. A higher nutritional composition was also recorded in soils with higher clay content relative to low clay soils. The results of leaf nutritional composition revealed no significant differences between the soil textural classes. The study concluded that moringa can be produced in many locations and on diverse soils of the Limpopo Province without negatively affecting leaf nutritional composition.
\end{abstract}

Keywords: locations, miracle plant, nutrients, soil textural classes, weather

\section{Introduction}

Moringa is gaining global attention due to its beneficial aspects such as food supplementation, medication, industrial purposes and for water purification properties (Fahey, 2005; Moyo et al., 2011; Oshunsanya et al., 2015; Lamidi et al., 2017). Almost all parts of the moringa tree are utilized for various purposes, for both human food and livestock feed as well as for its medicinal values (Lamidi et al., 2017). Moringa trees have been planted in many developing countries including South Africa, with the aim to combat malnutrition amongst poor families and significantly contribute to reducing food insecurity (Fahey, 2005; Jongrungruangchok et al., 2010; Gandji et al., 2018). The dried nutritional leaf powder can be used to fortify meals during dry seasons when there is a lack of other green leafy vegetables (Kumssa et al., 2017). There is considerable variation in moringa nutritional composition of the dried leaf powder depending on factors such as the genetic background of the plant and prevailing environmental conditions (Moyo et al., 2011).

Besides its nutritional composition, moringa is reported to increase soil fertility litter fall and its leaves can also be used as a nutrient-agent for biofertilizer production (Adiaha, 2017). A study conducted by Undie et al. (2013) showed that moringa leaves can serve 
as an alternative source of soil organic matter and can be a replacement for inorganic fertilizers for optimum crop production. The moringa tree is also strongly recommended for inclusion in agroforestry systems since its relatively deep root system minimizes moringa's competitiveness with companion crops for nutrient uptake in the system. This ultimately it helps to improve soil organic matter and fertility where moringa is grown (Ashfaq et al., 2012).

Moringa tree thrives under harsh conditions, where the majority of agricultural crops cannot survive, especially in tropical and subtropical areas (Leone et al., 2016). The tree grows best at a temperature ranging between 25 to $35^{\circ} \mathrm{C}$, but can still survive extreme temperatures of up to $48^{\circ} \mathrm{C}$ and tolerate a soil pH of 5.0 to 9.0 (Amaglo, 2006; Saini et al., 2016). Besides being tolerant from various environmental conditions, it is a fast growing tree that is known for its drought-tolerance abilities and can reach a height of 6 to $7 \mathrm{~m}$ within 12 months of establishment in areas receiving a rainfall of less than 400 and up to $1500 \mathrm{~mm} /$ annum (Morton, 1991; Odee, 1998; Amaglo, 2006; Yamato et al., 2009). Its survival to drought conditions is attributed to the presence of water storing organs in the root system and its symbiosis with mycorrhizal fungi (Yamato et al., 2009). Studies by Yamato et al. (2009), Muthukumar et al. (2006) and Cosme et al. (2014) reported on the colonization of arbuscular mycorrhizal (AM) fungi in moringa species and showed that the AM association contributes towards soil nutrients uptake, drought tolerance and disease resistance of the host plant.

Moringa is found in all countries, particularly those which experience malnutrition (Ashfaq et al., 2012). However, in South Africa, moringa is a fairly new crop that is grown by few farmers (Pakade et al., 2013) in provinces such as Kwa-Zulu Natal, Mpumalanga, and Limpopo (Lekgau, 2011). In Limpopo Province, the majority of farmers grow the tree on a small area of fewer than two hectares (Mabapa et al., 2017). Majority of such farmers grow the tree for household purposes. Mabapa et al. (2017), reported that moringa is produced in all districts of the Limpopo province. There is, however, limited information on the influence of soil characteristics on the mineral composition of moringa leaves. This study was established to investigate and compare the nutritional composition of Moringa oleifera leaves produced under diverse soil textural classes and types in the Limpopo Province.

\section{Materials and Methods}

\section{Study area}

The study was conducted during the summer season from November 2015 to January 2016 in all the five districts of the Limpopo Province $\left(23.4013^{\circ} \mathrm{S}, 29.4179^{\circ} \mathrm{E}\right)$, namely Capricorn, Sekhukhune, Waterberg, Mopani, and Vhembe. Limpopo province falls within the summer rainfall region of South Africa, with the western part being semi-arid and the eastern part largely sub-tropical. Typical rainfall for the province ranges from $200 \mathrm{~mm}$ in the hot dry areas to more than $1500 \mathrm{~mm}$ in the high rainfall areas, with most of it falling between October and April (Limpopo, D.F.E.D, 2004). The province experiences the highest temperatures during the months of October to March. Temperatures peak in December and January at about an average of $25^{\circ} \mathrm{C}$. The lowest temperatures occur in July with an average of $15^{\circ} \mathrm{C}$ (Tshiala et al., 2011). 


\section{Data collection}

Soil samples and fresh leaf samples were collected from the fields of 31 farmers who produce moringa on an area of 0.5 ha and above. The farmers were identified through a survey conducted by Mabapa et al. (2017). Profile of sampled moringa trees with the sampled areas is presented in Table 1. Fully expanded leaf samples were harvested from the lower, mid and upper parts of the five trees canopy from each location. A representative of five soil samples and gravimetric soil moisture were also determined from each location. Preliminary assessment of sampled soils revealed that the five districts had a variable textural class; therefore, the textural classes were grouped and used as treatments for the overall analysis of soil and leaf nutrition across locations.

Table 1. Locations and profile of moringa trees examined from the 5 districts in the Limpopo Province

\begin{tabular}{|c|c|c|c|c|c|}
\hline Number & District & Location/Area & $\begin{array}{c}\text { Tree Age } \\
\text { (Years) }\end{array}$ & $\begin{array}{c}\text { Soil Textural } \\
\text { Class }\end{array}$ & $\begin{array}{c}\text { Clay } \\
\text { Percentage }\end{array}$ \\
\hline 1 & Capricorn & Polokwane & 7 & Loamy Sand & 18 \\
\hline 2 & Capricorn & Matlala & 2 & Sandy Loam & 19.5 \\
\hline 3 & Capricorn & Polokwane & 2 & Sandy Loam & 25 \\
\hline 4 & Capricorn & Lebowakgomo & 3 & Sandy Clay Loam & 26.5 \\
\hline 5 & Capricorn & Ga-phasha & 3 & Sandy Clay Loam & 30 \\
\hline 6 & Capricorn & Makotse & 5 & Sandy Clay Loam & 31.5 \\
\hline 7 & Capricorn & Tooseng & 4 & Loamy Sand & 26 \\
\hline 8 & Mopani & Nkowankowa & 1 & Loamy Sand & 18.5 \\
\hline 9 & Mopani & Milliekloof & 1 & Loamy Sand & 17 \\
\hline 10 & Mopani & Woster & 3 & Sandy Loam & 21.5 \\
\hline 11 & Mopani & Ofcolaco & 2 & Sandy Clay Loam & 30 \\
\hline 12 & Mopani & Sekororo & 5 & Sandy Loam & 28 \\
\hline 13 & Mopani & Woster & 3 & Sandy Clay Loam & 31 \\
\hline 14 & Mopani & Lorraine & 4 & Sandy Clay & 42 \\
\hline 15 & Mopani & Baloon & 6 & Sandy Clay & 44 \\
\hline 16 & Mopani & Eiland & 4 & Sandy Loam & 17.5 \\
\hline 17 & Sekhukhune & Driekop & 10 & Sandy Loam & 16 \\
\hline 18 & Sekhukhune & Denilton & 4 & Loamy Sand & 20 \\
\hline 19 & Sekhukhune & Dithabaneng & 5 & Loamy Sand & 28 \\
\hline 20 & Vhembe & Makwarela & 3 & Sandy Clay Loam & 31.5 \\
\hline 21 & Vhembe & Thohoyandou & 3 & Sandy Loam & 27.5 \\
\hline 22 & Vhembe & Ha-Budeli & 3 & Sandy Clay & 38.5 \\
\hline 23 & Vhembe & Tshakhuma & 5 & Clay Loam & 49 \\
\hline 24 & Vhembe & Tshiande & 5 & Clay Loam & 52 \\
\hline 25 & Vhembe & Ha-Mutsha & 2 & Clay Loam & 56 \\
\hline 26 & Vhembe & Thohoyandou & 2 & Sandy Loam & 28 \\
\hline 27 & Vhembe & Lufule & 2 & Sandy Loam & 20.5 \\
\hline 28 & Vhembe & Ha-Dumase & 2 & Sandy Clay Loam & 30.5 \\
\hline 29 & Vhembe & Tshipise & 4 & Sandy Loam & 22 \\
\hline 30 & Waterberg & Mmapela & 3 & Clay & 60 \\
\hline 31 & Waterberg & Mokopane & 4 & Sandy Clay Loam & 32.5 \\
\hline
\end{tabular}

\section{Soil sampling and analysis}

Soil samples were taken under moringa canopy and $5 \mathrm{~m}$ away from the trees (as control) to determine the impact of the change in soil property beneath the moringa canopy area. Soils were sampled at a depth of 0 to 30 and 30 to $60 \mathrm{~cm}$ using an auger with the dimension of $8 \times 15 \mathrm{~cm}$, to determine physical and chemical characteristics (Tables 1 and 2) from each location. 
Table 2. Chemical and physical characteristics samples from the different locations in the Limpopo Province

\begin{tabular}{|c|c|c|c|c|c|c|c|c|c|c|c|c|c|c|c|c|}
\hline & & \multicolumn{15}{|c|}{ Locations } \\
\hline & & 1 & 2 & 3 & 4 & 5 & 6 & 7 & 8 & 9 & 10 & 11 & 12 & 13 & 14 & 15 \\
\hline \multicolumn{2}{|l|}{ Tree age } & 7 & 5 & 2 & 3 & 3 & 5 & 4 & 1 & 1 & 3 & 2 & 5 & 3 & 4 & 6 \\
\hline Soil Properties & $\begin{array}{c}\text { Depth } \\
\text { (cm) }\end{array}$ & & & & & & & & & & & & & & & \\
\hline Moringa N (\%) & $0-30$ & 0.04 & 0.04 & 0.14 & 0.08 & 0.08 & 0.08 & 0.06 & 0.04 & 0.04 & 0.04 & 0.40 & 0.04 & 0.11 & 0.04 & 0.04 \\
\hline Moringa N (\%) & $30-60$ & - & 0.04 & 0.10 & 0.07 & 0.04 & 0.04 & 0.04 & 0.04 & 0.04 & 0.04 & 0.40 & 0.05 & 0.04 & 0.04 & 0.04 \\
\hline Control N (\%) & $0-30$ & 0.04 & 0.04 & 0.09 & 0.04 & 0.08 & 0.04 & 0.10 & 0.06 & 0.06 & 0.04 & 0.40 & 0.09 & 0.09 & 0.04 & 0.04 \\
\hline Control N (\%) & $30-60$ & - & 0.04 & 0.05 & 0.04 & 0.05 & 0.04 & 0.04 & 0.04 & 0.04 & 0.04 & 0.40 & 0.04 & 0.04 & 0.04 & 0.04 \\
\hline Moringa $\mathrm{P}(\mathrm{mg} / \mathrm{L})$ & $0-30$ & 54 & 4 & 3 & 5 & 8 & 5 & 80 & 8 & 7 & 5 & 7 & 7 & 15 & 10 & 3 \\
\hline Moringa P (mg/L) & $30-60$ & - & 2 & 5 & 4 & 2 & 3 & 48 & 3 & 4 & 1 & 3 & 7 & 6 & 10 & 2 \\
\hline Control P (mg/L) & $0-30$ & 03 & 1 & 2 & 5 & 6 & 3 & 98 & 17 & 7 & 1 & 8 & 4 & 4 & 22 & 4 \\
\hline Control P (mg/L) & $30-60$ & - & 1 & 3 & 3 & 3 & 3 & 11 & 13 & 3 & 1 & 3 & 4 & 4 & 13 & 1 \\
\hline Moringa K (mg/L) & $0-30$ & 248 & 191 & 117 & 581 & 226 & 209 & 398 & 83 & 35 & 139 & 136 & 83 & 238 & 47 & 215 \\
\hline Moringa K (mg/L) & $30-60$ & - & 223 & 108 & 439 & 139 & 141 & 133 & 34 & 30 & 102 & 120 & 71 & 259 & 55 & 208 \\
\hline Control K (mg/L) & $0-30$ & 566 & 211 & 107 & 514 & 277 & 278 & 273 & 77 & 77 & 353 & 212 & 89 & 89 & 101 & 135 \\
\hline Control K (mg/L) & $30-60$ & - & 151 & 52 & 228 & 190 & 296 & 157 & 35 & 35 & 384 & 105 & 41 & 41 & 108 & 120 \\
\hline Moringa $\mathrm{Ca}(\mathrm{mg} / \mathrm{L})$ & $0-30$ & 968 & 593 & 1050 & 2964 & 2482 & 2353 & 737 & 354 & 472 & 582 & 743 & 1820 & 2400 & 414 & 550 \\
\hline Moringa $\mathrm{Ca}(\mathrm{mg} / \mathrm{L})$ & $30-60$ & - & 716 & 1003 & 2810 & 3040 & 2732 & 624 & 384 & 389 & 682 & 717 & 1970 & 1718 & 397 & 506 \\
\hline Control $\mathrm{Ca}(\mathrm{mg} / \mathrm{L})$ & $0-30$ & 660 & 321 & 897 & 2810 & 1326 & 1005 & 712 & 422 & 422 & 472 & 646 & 1004 & 1004 & 627 & 823 \\
\hline Control $\mathrm{Ca}(\mathrm{mg} / \mathrm{L})$ & $30-60$ & - & 243 & 715 & 3166 & 1903 & 1089 & 565 & 337 & 337 & 442 & 756 & 1164 & 1164 & 782 & 702 \\
\hline Moringa pH $(\mathrm{KCl})$ & $0-30$ & 6.37 & 4.99 & 5.56 & 6.52 & 7.53 & 6.61 & 7.84 & 5.57 & 5.73 & 7.44 & 5.97 & 6.54 & 6.73 & 7.06 & 4.95 \\
\hline Moringa $\mathrm{pH}(\mathrm{KCl})$ & $30-60$ & - & 5.20 & 5.58 & 6.94 & 7.16 & 6.91 & 8.02 & 5.18 & 5.30 & 7.38 & 5.57 & 6.26 & 7.52 & 7.04 & 4.95 \\
\hline Control pH (KCl) & $0-30$ & 5.49 & 4.78 & 4.41 & 6.88 & 5.86 & 6.92 & 7.82 & 5.51 & 5.51 & 5.53 & 5.13 & 6.64 & 6.64 & 7.46 & 6.1 \\
\hline Control pH $(\mathrm{KCl})$ & $30-60$ & - & 3.95 & 4.28 & 7.17 & 5.60 & 7.22 & 7.86 & 5.29 & 5.20 & 5.50 & 5.22 & 6.63 & 6.63 & 6.85 & 5.58 \\
\hline Moringa Org C (\%) & $0-30$ & 0.6 & 0.4 & 1.15 & 1.60 & 1.30 & 1.50 & 1 & 0.80 & 0.50 & 0.40 & 1.10 & 0.7 & 1.50 & 0.40 & 1.40 \\
\hline Moringa Org C (\%) & $30-60$ & - & 0.4 & 1 & 1.40 & 0.80 & 0.60 & 0.70 & 0.40 & 0.40 & 0.40 & 1.10 & 0.7 & 1.00 & 0.50 & 1.60 \\
\hline Control Org C (\%) & $0-30$ & 0.7 & 0.4 & 1.12 & 0.9 & 1.20 & 0.50 & 1.40 & 0.90 & 0.90 & 0.40 & 1.40 & 1.7 & 1.70 & 0.50 & 1.30 \\
\hline Control Org C (\%) & $30-60$ & - & 0.4 & 1 & 0.7 & 0.80 & 0.40 & 0.50 & 0.40 & 0.40 & 0.50 & 1.10 & 0.4 & 0.40 & 0.40 & 1.40 \\
\hline
\end{tabular}

APPLIED ECOLOGY AND ENVIRONMENTAL RESEARCH 19(2):953-970

http://www.aloki.hu • ISSN 15891623 (Print) • ISSN1785 0037 (Online)

DOI: http://dx.doi.org/10.15666/aeer/1902 953970

(๖) 2021, ALÖKI Kft., Budapest, Hungary 


\begin{tabular}{|c|c|c|c|c|c|c|c|c|c|c|c|c|c|c|c|c|c|}
\hline & & \multicolumn{16}{|c|}{ Locations } \\
\hline & & 16 & 17 & 18 & 19 & 20 & 21 & 22 & 23 & 24 & 25 & 26 & 27 & 28 & 29 & 30 & 31 \\
\hline \multicolumn{2}{|l|}{ Tree age } & 4 & 10 & 4 & 5 & 3 & 3 & 3 & 5 & 5 & 2 & 2 & 2 & 2 & 4 & 3 & 4 \\
\hline Soil Properties & $\begin{array}{c}\text { Depth } \\
\text { (cm) }\end{array}$ & & & & & & & & & & & & & & & & \\
\hline Moringa N (\%) & $0-30$ & 0.04 & 0.06 & 0.04 & 0.04 & 0.06 & 0.07 & 0.11 & 0.08 & 0.19 & 0.12 & 0.09 & 0.04 & 0.12 & 0.05 & 0.15 & 0.08 \\
\hline Moringa N (\%) & $30-60$ & 0.04 & 0.09 & 0.04 & 0.04 & 0.04 & 0.09 & 0.04 & 0.08 & 0.07 & 0.20 & 0.21 & 0.07 & 0.04 & 0.04 & 0.05 & 0.05 \\
\hline Control N (\%) & $0-30$ & 0.12 & 0.08 & 0.08 & 0.04 & 0.11 & 0.11 & 0.06 & 0.09 & 0.16 & 0.33 & 0.04 & 0.04 & 0.04 & 0.04 & 0.04 & 0.11 \\
\hline Control N (\%) & $30-60$ & 0.04 & 0.06 & 0.06 & 0.05 & 0.07 & 0.07 & 0.09 & 0.10 & 0.07 & 0.27 & 0.18 & 0.04 & 0.04 & 0.04 & 0.1 & 0.1 \\
\hline Moringa $\mathrm{P}(\mathrm{mg} / \mathrm{L})$ & $0-30$ & 46 & 100 & 36 & 20 & 51 & 44 & 7 & 83 & 15 & 34 & 22 & 28 & 8 & 11 & 26 & 53 \\
\hline Moringa P (mg/L) & $30-60$ & 39 & 54 & 8 & 3 & 10 & 13 & 22 & 59 & 20 & 26 & 13 & 26 & 2 & 7 & 3 & 2 \\
\hline Control P (mg/L) & $0-30$ & 32 & 16 & 16 & 9 & 2 & 2 & 12 & 17 & 15 & 11 & 15 & 67 & 14 & 14 & 2 & 4 \\
\hline Control P (mg/L) & $30-60$ & 20 & 9 & 9 & 3 & 1 & 1 & 46 & 9 & 6 & 6 & 12 & 3 & 8 & 8 & 5 & 2 \\
\hline Moringa K (mg/L) & $0-30$ & 238 & 389 & 331 & 131 & 512 & 603 & 185 & 407 & 282 & 331 & 183 & 202 & 158 & 79 & 566 & 164 \\
\hline Moringa K (mg/L) & $30-60$ & 228 & 372 & 333 & 104 & 253 & 302 & 238 & 336 & 168 & 294 & 267 & 210 & 50 & 69 & 148 & 49 \\
\hline Control K (mg/L) & $0-30$ & 155 & 292 & 219 & 294 & 187 & 187 & 999 & 200 & 133 & 254 & 270 & 357 & 91 & 91 & 116 & 149 \\
\hline Control K (mg/L) & $30-60$ & 126 & 265 & 226 & 96 & 213 & 213 & 482 & 195 & 77 & 194 & 134 & 126 & 80 & 80 & 169 & 111 \\
\hline Moringa $\mathrm{Ca}(\mathrm{mg} / \mathrm{L})$ & $0-30$ & 965 & 1572 & 827 & 1156 & 1641 & 2602 & 2453 & 1653 & 1842 & 1738 & 1120 & 1050 & 1875 & 970 & 3442 & 902 \\
\hline Moringa $\mathrm{Ca}(\mathrm{mg} / \mathrm{L})$ & $30-60$ & 992 & 1530 & 574 & 1780 & 856 & 1882 & 1670 & 1610 & 2686 & 1719 & 1833 & 1044 & 869 & 899 & 3174 & 916 \\
\hline Control $\mathrm{Ca}(\mathrm{mg} / \mathrm{L})$ & $0-30$ & 1314 & 1119 & 119 & 1467 & 741 & 2741 & 1849 & 979 & 1668 & 1192 & 1942 & 1213 & 629 & 629 & 2587 & 1491 \\
\hline Control $\mathrm{Ca}(\mathrm{mg} / \mathrm{L})$ & $30-60$ & 1364 & 1301 & 310 & 1641 & 926 & 2917 & 2326 & 812 & 2730 & 1040 & 1751 & 515 & 625 & 625 & 2813 & 1694 \\
\hline Moringa $\mathrm{pH}(\mathrm{KCl})$ & $0-30$ & 6.86 & 7.61 & 6.51 & 7.72 & 7.5 & 7.46 & 6.63 & 7.01 & 5.64 & 7.6 & 5.78 & 6.5 & 5.85 & 6.36 & 7.44 & 6.5 \\
\hline Moringa pH (KCl) & $30-60$ & 6.74 & 7.48 & 5.67 & 7.64 & 7.39 & 7.15 & 7.2 & 6.88 & 7.42 & 7.31 & 5.66 & 6.39 & 5.46 & 6.24 & 7.21 & 6.36 \\
\hline Control pH (KCl) & $0-30$ & 5.60 & 4.57 & 4.50 & 7.70 & 7.02 & 7.02 & 7.37 & 5.76 & 5.93 & 5.12 & 6.94 & 6.46 & 5.86 & 5.86 & 7.18 & 6.72 \\
\hline Control pH (KCl) & $30-60$ & 5.52 & 5 & 5.00 & 7.60 & 7 & 7 & 7.09 & 5.56 & 6.96 & 4.82 & 5.9 & 5.06 & 5.98 & 5.98 & 7.21 & 6.83 \\
\hline Moringa Org C (\%) & $0-30$ & 0.70 & 0.7 & 0.4 & 0.4 & 0.6 & 0.9 & 1.40 & 1.7 & 2.7 & 1.80 & 1.4 & 0.4 & 1.3 & 1.1 & 1.7 & 1.1 \\
\hline Moringa Org C (\%) & $30-60$ & 0.40 & 0.7 & 0.4 & 0.4 & 0.4 & 0.6 & 0.80 & 1.7 & 1.4 & 2.40 & 2.8 & 1.0 & 0.7 & 0.7 & 0.6 & 0.7 \\
\hline Control Org C (\%) & $0-30$ & 1.50 & 0.8 & 0.5 & 0.4 & 1.4 & 1.4 & 1.30 & 1.6 & 2.2 & 3.60 & 0.7 & 0.7 & 0.4 & 0.4 & 0.4 & 1.1 \\
\hline Control Org C (\%) & $30-60$ & 0.06 & 0.5 & 0.3 & 0.4 & 10 & 6 & 1.20 & 1.6 & 1.5 & 3.10 & 2.2 & 0.4 & 0.4 & 0.4 & 0.9 & 0.4 \\
\hline
\end{tabular}


Gravimetric soil moisture percentage was also determined from the same depths. Ziplock plastic bags were used to keep soil for moisture retention before measurement. Fresh soil moisture weight was determined immediately after sampling using a battery-operated top loading weighing balance (RADWAG, W/C6/12/C1/R model). Soils were placed in aluminum drying pans and dried in an oven (Scientific oven Economy, 240 litres, Model 223) for 24 hours at a temperature of $105^{\circ} \mathrm{C}$. Gravimetric soil moisture percentage was determined when the soil samples had reached a constant weight, using a method described by Black (1965). Soils textural classes were determined based on particle size distribution and soil samples were analysed for $\mathrm{P}, \mathrm{K}, \mathrm{Ca}, \mathrm{Mg}, \mathrm{Zn}, \mathrm{Mn}, \mathrm{Cu}(\mathrm{mg} / \mathrm{L}), \mathrm{pH}$ $(\mathrm{KCl})$, organic carbon, total $\mathrm{N}(\%)$, using analytical methods used by the soil fertility and analytical services section in Kwa-Zulu Natal (Manson and Roberts, 2000).

\section{Nutrients determination in moringa leaves}

Samples of moringa leaves collected from different locations were shade-dried at room temperature $\left(24^{\circ} \mathrm{C}\right)$ for 72 hours, to ease the defoliation from the rachis. Dried leaf samples were ground to pass through a $2 \mathrm{~mm}$ sieve and samples from the aforementioned locations within each soil textural class were bulked and mixed thoroughly. A $10 \mathrm{~g}$ sample of a fine fraction was used to determine their chemical composition. The analyses were carried out in triplicate. Crude protein was determined using the Kjeldahl method (AOAC, 1990). Other minerals such as N, P, Ca, and Fe were determined using atomic absorption procedure (Gaines and Mitchell, 1979).

\section{Statistical analysis}

The data collected were subjected to analysis of variance using Statistix 10.0 to determine the effect soil texture on measured variables. Where significant F-values from the treatment effect were found, means were separated by the least significant difference (LSD) at a probability level of 0.05. Linear correlation and regression analyses were performed using Statistix 10.0 and Microsoft Excel to determine the relationship between soil and leaf nutrient properties of moringa trees.

\section{Results}

Profile of sampled locations which included districts, location, tree age and soil textural classes are presented in Table 1. The results showed that moringa is grown in all the districts of the Limpopo Province. It was observed that 55\% of the farmers had three years and lesser experience in moringa farming. Majority of the sampled locations were dominated by sandy loam soil.

The mean annual temperature, annual rainfall, locations where moringa is growing in the Limpopo Province and soil textural classes are shown in Figs. 1 and 2. Many areas of the Limpopo Province experience high temperature to an extent such that the average could be more than $23^{\circ} \mathrm{C}$ (Fig. 1). The province also receives erratic annual rainfall ranging between 300 to $500 \mathrm{~mm}$ (Fig. 2).

Figs. 1 and 2 showed that moringa can grow on various soils textural classes depending on the location where a farmer is growing the trees in the Limpopo Province. Weather data collected from the nearest weather station of each location during the study period is shown in Fig. 3. It was observed that the average maximum temperature ranged 
between 30 to $35^{\circ} \mathrm{C}$ with minimum temperature raging between 15 to $22^{\circ} \mathrm{C}$ and a total rainfall of between 75 to $200 \mathrm{~mm}$ during the study period (Fig. 3).

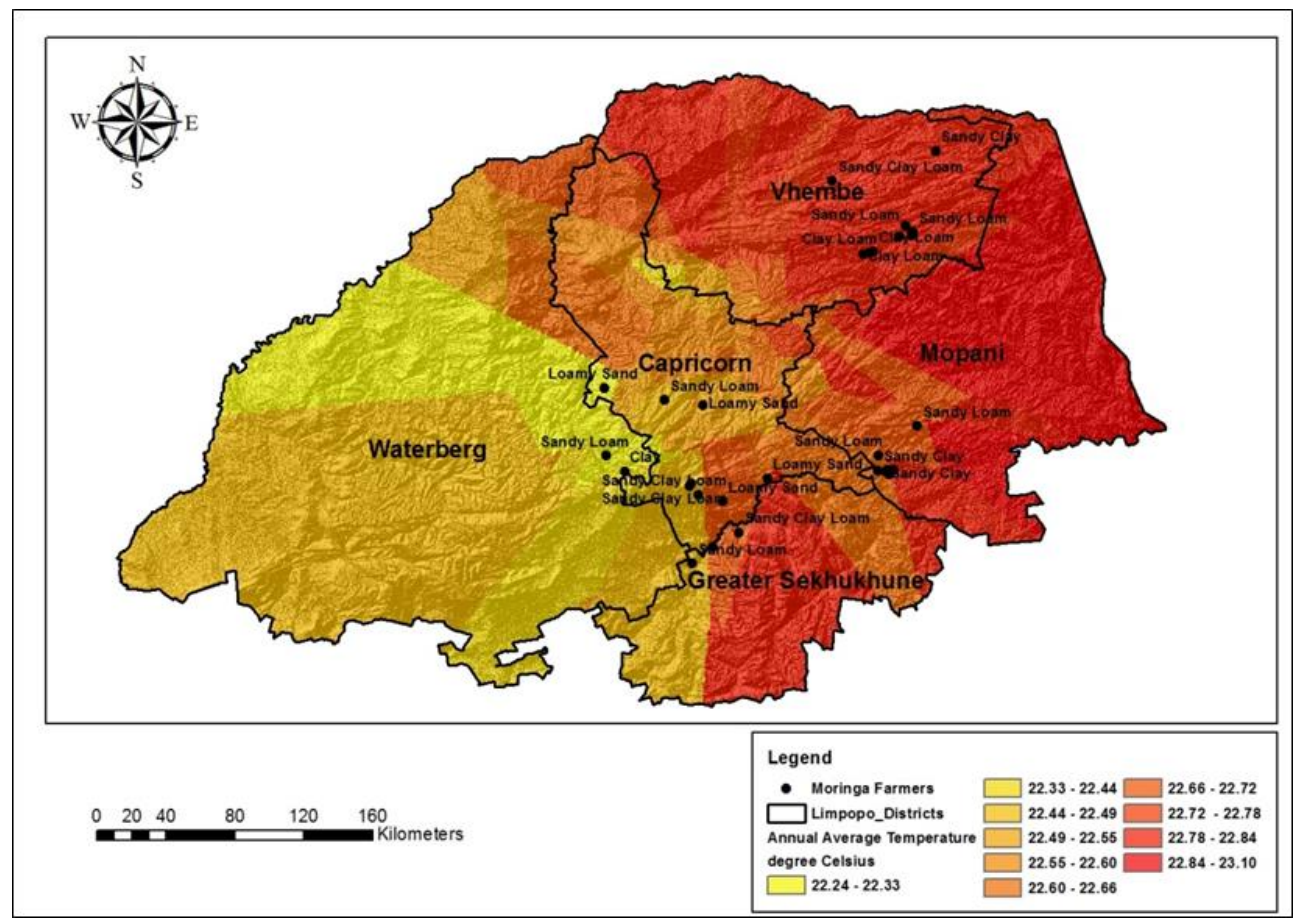

Figure 1. Average annual temperature and soil textural classes from various locations where moringa is growing in Limpopo Province

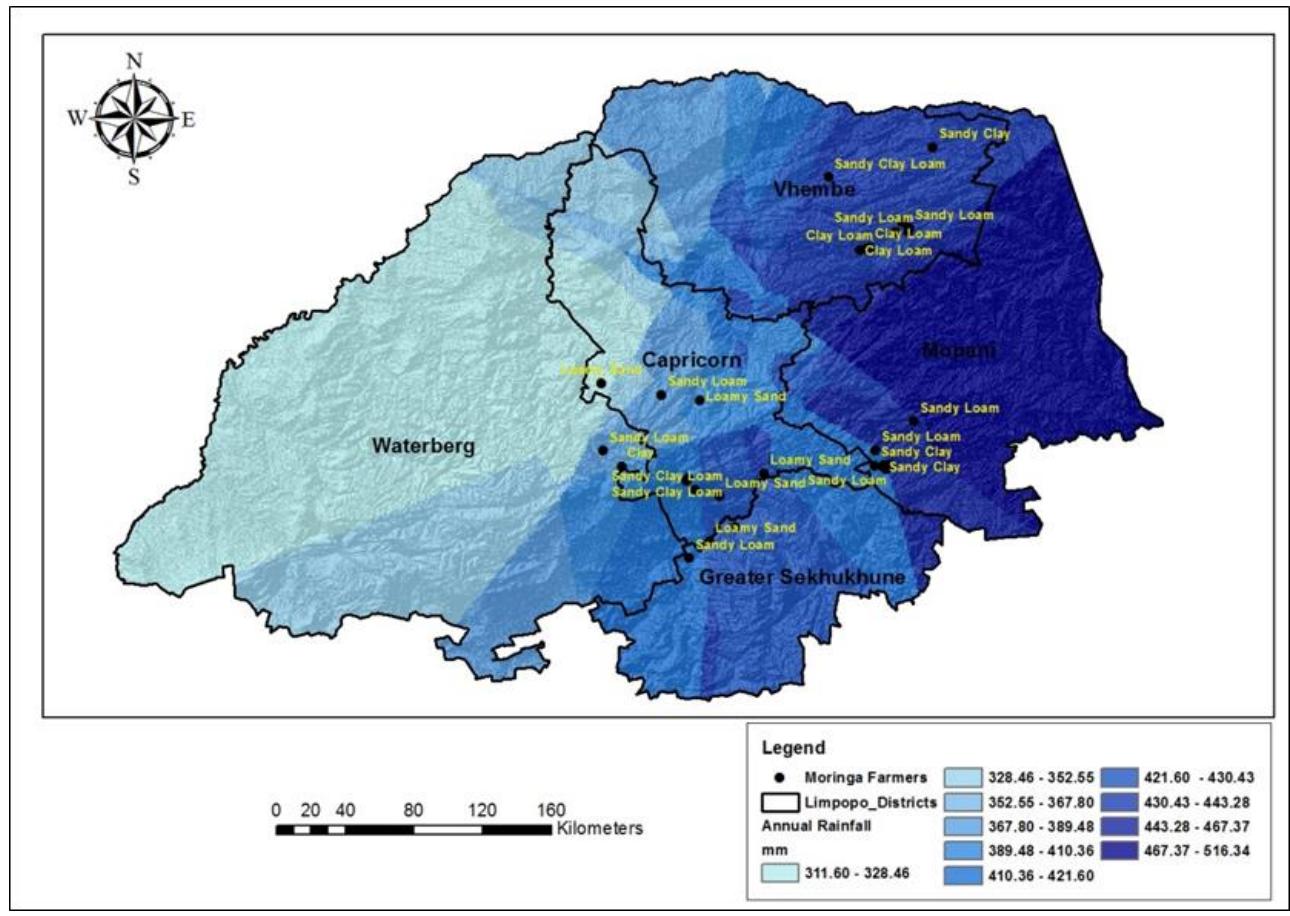

Figure 2. Total annual rainfall and soil textural classes from various locations where moringa is growing in Limpopo Province 


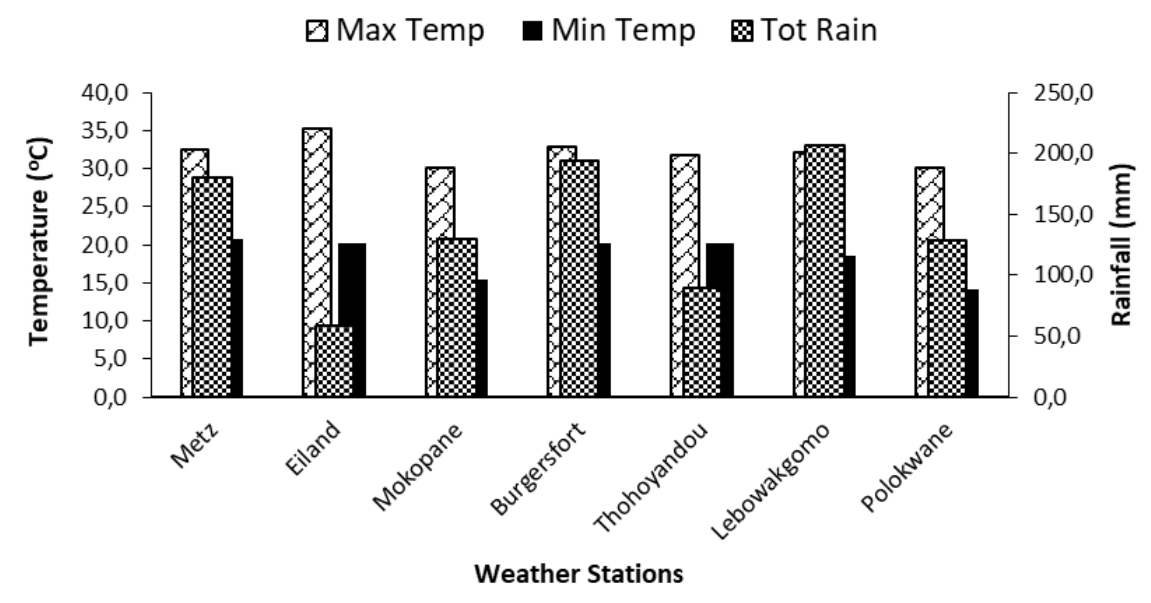

Figure 3. Weather data collected from 2011 until 2016 during the study from selected locations in Limpopo Province

Chemical properties of the soil samples collected from the selected 31 locations are shown in Table 2. In many cases, the chemical composition in the soil at 0 to $30 \mathrm{~cm}$ depth was relatively higher compared to the lower depth of $60 \mathrm{~cm}$ in both the control and moringa canopy samples (Table 2).

Nitrogen and phosphorus were found to be very low at all locations. The nitrogen content increased slightly by 33 percent mainly in soils with a higher clay content of more than 30 percent, while a reduction of 35 percent was also noticed in sandy soils and the constant results between control and nitrogen content were 32 percent (Table 2). The range for phosphorus concentration was between 3 and $100 \mathrm{mg} / \mathrm{l}$ under moringa canopy and 2 and $98 \mathrm{mg} / \mathrm{l}$ under control. There was also a decrease in $\mathrm{P}$ content with an increase in sampling depth.

Out of 31 locations, 17 (55 percent) locations recorded higher potassium content under moringa canopy compared to the control. A total of 22 (71 percent) locations also showed an increase in calcium content where there was moringa trees (Table 2). The soil pH ranged from 4.95 to 8.02, under moringa trees, while the control ranged from 3.5 to 7.86 . The results thus reveal that moringa may have the potential to ameliorate acidic soils. The soil organic carbon ranged between 0.4 to $2.7 \%$ under moringa canopy and 0.06 to $3.6 \%$ under the control (Table 2). It was observed that where soils had high clay content (>30 percent) the amount of organic carbon under moringa canopy had slightly increased.

A significant positive relationship was observed between soil nitrogen with soil calcium $\left(0.40^{* *}\right)$ and organic carbon $(0.73 * * *)$. Soil calcium also had a positive relationship with organic carbon $\left(0.30^{* *}\right)$ and soil potassium $\left(0.45^{* *}\right)$. As the tree matures the amount of phosphorus increased in many occasions which led to a positive relationship of $0.27^{*}$ (Fig. 4). Soil $\mathrm{pH}$ had a positive relationship with soil phosphorus $(0.23 *)$, potassium $\left(0.21^{*}\right)$ and calcium $(0.13 *)$ (Fig. 5).

Findings from this study showed that the concentration of soil nitrogen, phosphorus, potassium, calcium and organic carbon was significantly dependent on soil textural class whereas $\mathrm{pH}$ was not affected (Table 3). It was observed that an increase in clay content (>45 percent) in the soil, improved the soil chemical composition. Soil potassium and calcium content were more than 550 and $3000 \mathrm{mg} / \mathrm{L}$ under the clay textured soil (Table 3). 


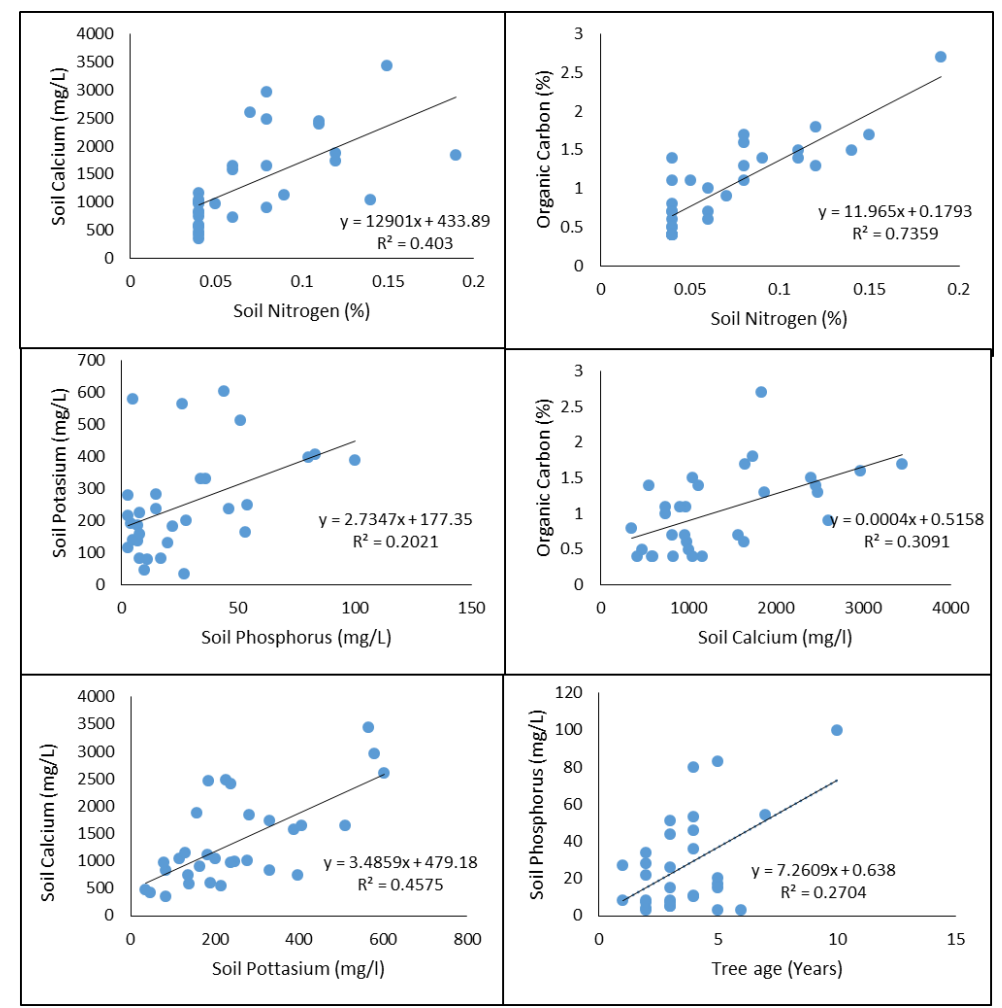

Figure 4. Correlation and linear relationship effects of tree age and soil properties under the moringa tree canopy

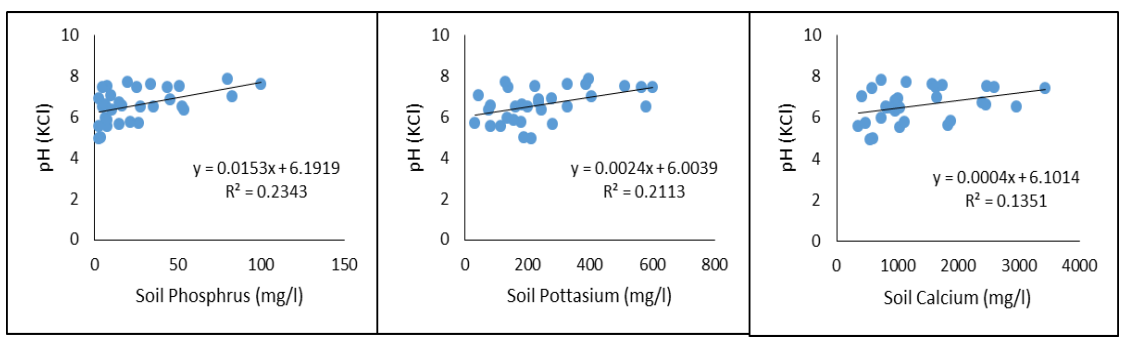

Figure 5. Correlation and linear relationship analysis of soil pH and other physical properties under moringa tree canopy

Table 3. Effect of soil textural class on physical and chemical properties of soil sampled under moringa trees at different locations in Limpopo Province

\begin{tabular}{|c|c|c|c|c|c|c|}
\hline \multirow[b]{2}{*}{ Treatment } & \multicolumn{6}{|c|}{ Soil Chemical properties } \\
\hline & $\begin{array}{c}\text { Soil N } \\
(\%)\end{array}$ & $\begin{array}{c}\text { Soil P } \\
(\mathrm{mg} / \mathrm{L})\end{array}$ & $\begin{array}{l}\text { Soil K } \\
\text { (mg/L) }\end{array}$ & $\begin{array}{l}\text { Soil Ca } \\
(\mathrm{mg} / \mathrm{L})\end{array}$ & $\begin{array}{c}\mathbf{p H} \\
(\mathrm{KCl})\end{array}$ & $\begin{array}{c}\text { Soil Org C } \\
(\%)\end{array}$ \\
\hline Clay & $0.15^{\mathrm{a}}$ & $26.00^{b}$ & $566.00^{\mathrm{a}}$ & $3442.0^{\mathrm{a}}$ & $7.44^{\mathrm{a}}$ & $1.70^{\mathrm{a} b}$ \\
\hline Clay Loam & $0.13^{\mathrm{a}}$ & $44.00^{\mathrm{a}}$ & $340.00^{\mathrm{ab}}$ & $1751.5^{b}$ & $6.75^{\mathrm{a}}$ & $2.06^{\mathrm{a}}$ \\
\hline Sandy Clay Loam & $0.08^{\mathrm{b}}$ & $18.75^{\mathrm{c}}$ & $286.63^{\mathrm{ab}}$ & $1744.3^{b}$ & $6.69^{a}$ & $1.12^{\mathrm{bc}}$ \\
\hline Sandy Clay & $0.06^{\mathrm{b}}$ & $6.66^{\mathrm{d}}$ & $222.40^{b}$ & $1139.3^{b c}$ & $6.21^{\mathrm{a}}$ & $1.06^{\mathrm{bcd}}$ \\
\hline Sandy Loam & $0.06^{\mathrm{b}}$ & $28.00^{\mathrm{ab}}$ & $149.00^{b}$ & $1132.4^{b c}$ & $6.51^{\mathrm{a}}$ & $0.82^{\mathrm{cd}}$ \\
\hline Loamy Sand & $0.04^{\mathrm{b}}$ & $37.50^{\mathrm{a}}$ & $204.33^{b}$ & $755.33^{c}$ & $6.62^{\mathrm{a}}$ & $0.61^{\mathrm{d}}$ \\
\hline $\begin{array}{c}\text { LSD }_{0.05} \\
\text { Significance }\end{array}$ & $\begin{array}{l}0.07 \\
* * *\end{array}$ & $\begin{array}{c}25.34 \\
* *\end{array}$ & $\begin{array}{c}146 \\
* *\end{array}$ & $\begin{array}{c}646.27 \\
* * *\end{array}$ & $\begin{array}{l}-- \\
\text { ns }\end{array}$ & $\begin{array}{l}0.39 \\
* * *\end{array}$ \\
\hline
\end{tabular}

Significance levels: $* \mathrm{P}<0.05, * * \mathrm{P}<0.01, * * * \mathrm{P}<0.001$, ns means not significant 
Findings from the study further revealed that soil textural classes containing higher clay content under the moringa tree had a more positive influence on other soil chemical properties as compared to the control (Fig. 6). High clay content had a significant influence on soil phosphorus, potassium, calcium, potassium and organic carbon (Fig. 6). Gravimetric soil moisture was relatively low $(<10 \%)$ across all soil textural classes. However, the soil moisture was significantly higher under the moringa tree as compared to the control. Gravimetric soil moisture ranged between $4-8.3 \%$ under moringa canopies and from 2.5-7.8 under the control (Fig. 7).

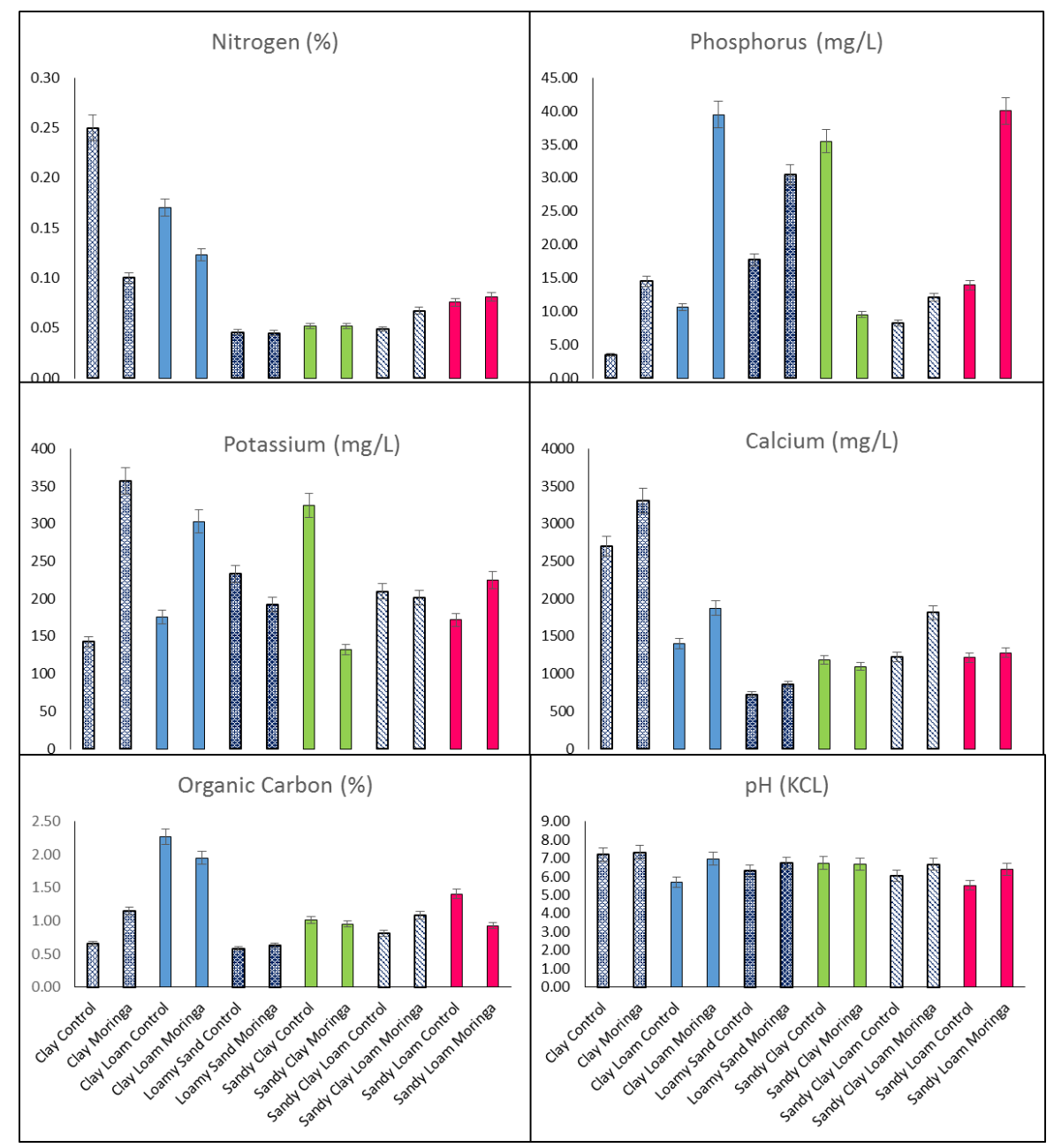

Figure 6. Textural classes and chemical properties of soils sampled under moringa trees and control (5 $m$ away) at different locations in Limpopo Province

Findings from this study showed that soil textural classes did not significantly affect the nutritional composition of moringa leaves. Across the various textural classes, leaf nutritional composition was however within levels required to meet dietary requirements for both humans and livestock (Table 4). An assessment of association test among the nutritional parameters studied showed a positive linear regression between leaf phosphorus content and leaf nitrogen $\left(0.39^{* *}\right)$ and that of leaf protein $\left(0.32^{* *}\right)$ content (Fig. 8). 


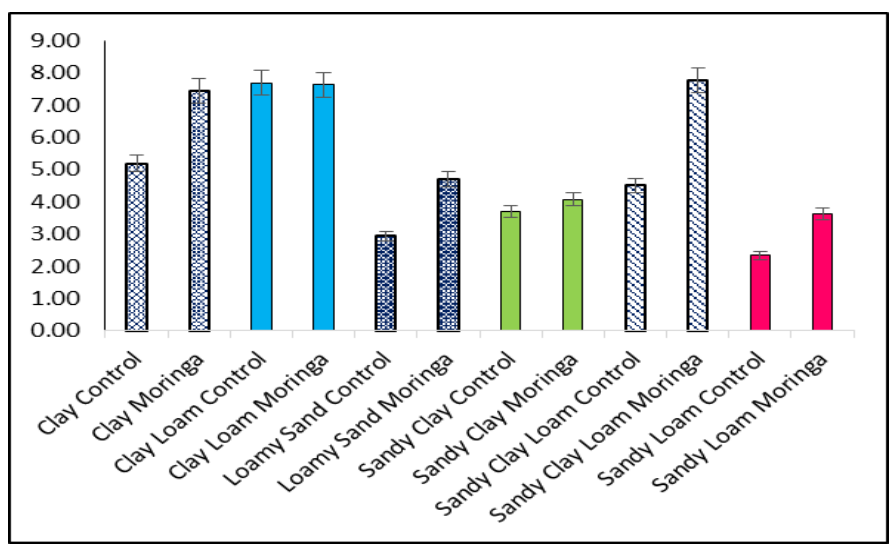

Figure 7. Textural classes and gravimetric moisture (\%) of soils sampled under moringa trees and control (5 $m$ away) at different locations in Limpopo Province

Table 4. Effect of soil textural class on the nutritional composition of moringa leaf powder obtained from different locations in Limpopo Province

\begin{tabular}{c|c|c|c|c|c}
\hline Treatment & Leaf N (\%) & Crude Protein (\%) & Leaf Ca (\%) & Leaf P (\%) & Leaf Fe (mg/kg) \\
\hline Clay & $5.31^{\mathrm{a}}$ & $33.20^{\mathrm{a}}$ & $2.68^{\mathrm{a}}$ & $0.27^{\mathrm{a}}$ & $144.00^{\mathrm{a}}$ \\
Clay Loam & $3.99^{\mathrm{a}}$ & $26.38^{\mathrm{a}}$ & $1.64^{\mathrm{a}}$ & $0.21^{\mathrm{a}}$ & $174.00^{\mathrm{a}}$ \\
Sandy Clay Loam & $4.70^{\mathrm{a}}$ & $29.42^{\mathrm{a}}$ & $2.21^{\mathrm{a}}$ & $0.23^{\mathrm{a}}$ & $164.63^{\mathrm{a}}$ \\
Sandy Clay & $4.60^{\mathrm{a}}$ & $28.76^{\mathrm{a}}$ & $2.60^{\mathrm{a}}$ & $0.21^{\mathrm{a}}$ & $163.67^{\mathrm{a}}$ \\
Sandy Loam & $4.68 \mathrm{a}$ & $29.28^{\mathrm{a}}$ & $2.26^{\mathrm{a}}$ & $0.23^{\mathrm{a}}$ & $151.90^{\mathrm{a}}$ \\
Loamy Sand & $5.21^{\mathrm{a}}$ & $31.55^{\mathrm{a}}$ & $1.99^{\mathrm{a}}$ & $0.28^{\mathrm{a}}$ & $167.00^{\mathrm{a}}$ \\
\hline LSD & --.05 & -- & -- & -- & -- \\
Significance & $\mathrm{ns}$ & $\mathrm{ns}$ & $\mathrm{ns}$ & $\mathrm{ns}$ & $\mathrm{ns}$ \\
\hline
\end{tabular}

Significance levels: ns means none significance

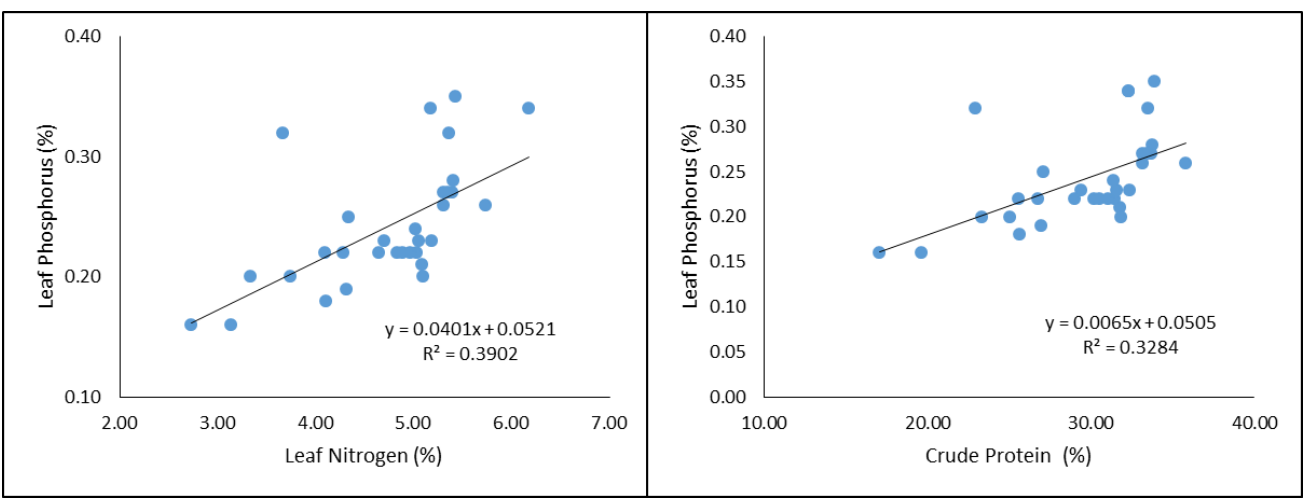

Figure 8. Regression and linear relationships analysis of moringa leaf phosphorus, nitrogen, and crude protein

Analysis among soil nutrient ions revealed several significant positive correlations extending to the following: nitrogen and calcium $(0.63 * * *)$; nitrogen and organic carbon $\left(0.86^{* * *}\right)$, potassium and $\mathrm{pH}\left(0.46^{* *}\right)$; potassium and calcium $\left(0.68^{* * *}\right)$; calcium and $\mathrm{pH}\left(0.37^{*}\right)$ and lastly calcium and organic carbon $\left(0.56^{* * *}\right)$ (Table 5). Gravimetric soil moisture did not correlate with any of the parameters measured whereas tree age only revealed a moderate positive correlation with phosphorous $\left(0.52^{* * *}\right)$ (Table 5). 
Table 5. Pearson's correlation between soil properties and moringa leaf nutritional composition obtained from different locations of the Limpopo Province

\begin{tabular}{|c|c|c|c|c|c|c|c|c|c|c|c|c|}
\hline & $\begin{array}{c}\text { Gravimetric } \\
\text { soil moisture } \\
(\%)\end{array}$ & $\begin{array}{c}\text { Tree age } \\
\text { (Yrs) }\end{array}$ & $\begin{array}{c}\text { Soil N } \\
(\%)\end{array}$ & $\begin{array}{c}\text { Soil P } \\
(\mathrm{mg} / \mathrm{L})\end{array}$ & $\begin{array}{l}\text { Soil K } \\
(\mathrm{mg} / \mathrm{L})\end{array}$ & $\begin{array}{l}\text { Soil Ca } \\
(\mathrm{mg} / \mathrm{L})\end{array}$ & $\underset{(\mathbf{K C l})}{\mathbf{p H}}$ & $\begin{array}{c}\text { Soil Org C } \\
(\%)\end{array}$ & $\begin{array}{c}\text { Leaf N } \\
(\%)\end{array}$ & $\begin{array}{c}\text { Crude } \\
\text { Protein }(\%)\end{array}$ & $\begin{array}{c}\text { Leaf Ca } \\
(\%)\end{array}$ & $\begin{array}{c}\text { Leaf P } \\
(\%)\end{array}$ \\
\hline $\begin{array}{c}\text { Gravimetric } \\
\text { soil }\end{array}$ & & & & & & & & & & & & \\
\hline $\begin{array}{c}\text { Moisture } \\
(\%)\end{array}$ & 1 & & & & & & & & & & & \\
\hline $\begin{array}{c}\text { Tree Age } \\
\text { (Yrs) }\end{array}$ & $-0.14 \pm 0.43^{\mathrm{ns}}$ & 1 & & & & & & & & & & \\
\hline $\begin{array}{c}\text { Soil N } \\
(\%)\end{array}$ & $0.16 \pm 0.39^{\text {ns }}$ & $-0.14 \pm 0.45^{\text {ns }}$ & 1 & & & & & & & & & \\
\hline $\begin{array}{c}\text { Soil P } \\
(\mathrm{Mg} / \mathrm{L})\end{array}$ & $-0.20 \pm 0.27 \mathrm{~ns}$ & $0.52 \pm 0.00 * * *$ & $-0.09 \pm 0.65^{n s}$ & 1 & & & & & & & & \\
\hline $\begin{array}{c}\text { Soil K } \\
(\mathrm{Mg} / \mathrm{L})\end{array}$ & $-0.04 \pm 0.82^{\mathrm{ns}}$ & $0.19 \pm 0.31^{\mathrm{ns}}$ & $0.27 \pm 0.14^{\mathrm{ns}}$ & $0.45 \pm 0.01 * *$ & 1 & & & & & & & \\
\hline $\begin{array}{l}\text { Soil Ca } \\
(\mathrm{Mg} / \mathrm{L})\end{array}$ & $0.29 \pm 0.11^{\mathrm{ns}}$ & $-0.03 \pm 0.89^{\mathrm{ns}}$ & $0.63 \pm 0.00 * * *$ & $0.03 \pm 0.88^{\mathrm{ns}}$ & $\begin{array}{c}0.68 \pm 0.00 \\
* * *\end{array}$ & 1 & & & & & & \\
\hline $\begin{array}{c}\text { pH } \\
(\text { KCL })\end{array}$ & $0.11 \pm 0.57^{\mathrm{ns}}$ & $0.27 \pm 0.15^{\mathrm{ns}}$ & $-0.04 \pm 0.85^{\mathrm{ns}}$ & $0.48 \pm 0.01 * *$ & $0.46 \pm 0.01 * *$ & $0.37 \pm 0.04 *$ & 1 & & & & & \\
\hline $\begin{array}{c}\text { Soil Org C } \\
(\%)\end{array}$ & $0.28 \pm 0.13^{\text {ns }}$ & $-0.06 \pm 0.74 \mathrm{~ns}$ & $0.86 \pm 0.00 * * *$ & $-0.08 \pm 0.67^{\mathrm{ns}}$ & $0.27 \pm 0.14^{\mathrm{ns}}$ & $0.56 \pm 0.00 * * *$ & $-0.150 .41^{\mathrm{ns}}$ & 1 & & & & \\
\hline $\begin{array}{c}\text { Leaf N } \\
(\%)\end{array}$ & $-0.05 \pm 0.79^{\mathrm{ns}}$ & $0.09 \pm 0.64 \mathrm{~ns}$ & $-0.12 \pm 0.51 \mathrm{~ns}$ & $0.25 \pm 0.17^{\mathrm{ns}}$ & $0.33 \pm 0.07^{\mathrm{ns}}$ & $0.01 \pm 0.94 \mathrm{~ns}$ & $0.160 .39^{\mathrm{ns}}$ & $-0.22 \pm 0.23$ ns & 1 & & & \\
\hline $\begin{array}{c}\text { Crude } \\
\text { Protein } \\
(\%)\end{array}$ & $-0.01 \pm 0.94 \mathrm{~ns}$ & $0.11 \pm 0.56^{\mathrm{ns}}$ & $-0.03 \pm 0.89^{\mathrm{ns}}$ & $0.16 \pm 0.37^{\mathrm{ns}}$ & $0.33 \pm 0.07^{\mathrm{ns}}$ & $0.07 \pm 0.70^{\mathrm{ns}}$ & $0.070 .72^{\mathrm{ns}}$ & $-0.14 \pm 0.44^{\mathrm{ns}}$ & $0.96 \pm 0.00 * * *$ & 1 & & \\
\hline $\begin{array}{c}\text { Leaf Ca } \\
(\%)\end{array}$ & $0.23 \pm 0.21 \mathrm{~ns}$ & $0.03 \pm 0.85^{\mathrm{ns}}$ & $-0.16 \pm 0.38$ & $-0.05 \pm 0.79^{\text {ns }}$ & $0.23 \pm 0.22^{\mathrm{ns}}$ & $0.24 \pm 0.19^{\mathrm{ns}}$ & $0.290 .11^{\mathrm{ns}}$ & $-0.19 \pm 0.30^{\mathrm{ns}}$ & $0.11 \pm 0.56^{\mathrm{ns}}$ & $0.09 \pm 0.63^{\mathrm{ns}}$ & 1 & \\
\hline $\begin{array}{c}\text { Leaf P } \\
(\%)\end{array}$ & $-0.19 \pm 0.28 \mathrm{~ns}$ & $0.09 \pm 0.61 \mathrm{~ns}$ & $-0.03 \pm 0.86^{\mathrm{ns}}$ & $0.37 \pm 0.06^{\mathrm{ns}}$ & $0.24 \pm 0.19 \mathrm{~ns}$ & $-0.04 \pm 0.84 \mathrm{~ns}$ & $-0.02 \pm 0.93^{\mathrm{ns}}$ & $-0.14 \pm 0.47^{\mathrm{ns}}$ & $0.63 \pm 0.00 * * *$ & $\begin{array}{c}0.57 \pm 0.00 \\
* * *\end{array}$ & $-0.04 \pm 0.84 \mathrm{~ns}$ & 1 \\
\hline $\begin{array}{l}\text { Leaf Fe } \\
(\mathrm{mg} / \mathrm{kg})\end{array}$ & $-0.03 \pm 0.86^{\mathrm{ns}}$ & $0.07 \pm 0.69^{\mathrm{ns}}$ & $-0.02 \pm 0.92^{\mathrm{ns}}$ & $0.17 \pm 0.36^{\mathrm{ns}}$ & $0.16 \pm 0.39$ ns & $0.04 \pm 0.81^{\mathrm{ns}}$ & $0.21 \pm 0.26^{\mathrm{ns}}$ & $-0.09 \pm 0.60^{\mathrm{ns}}$ & $-0.25 \pm 0.17^{\mathrm{ns}}$ & $-0.25 \pm 0.17^{\mathrm{ns}}$ & $0.13 \pm 0.48^{\mathrm{ns}}$ & $-0.18 \pm 0.33^{\text {ns }}$ \\
\hline
\end{tabular}

Significance levels: $* \mathrm{P}<0.05, * * \mathrm{P}<0.01, * * * \mathrm{P}<0.001$, ns- not significant 


\section{Discussion}

During the study period, Limpopo Province experienced high temperatures accompanied by erratic rainfall. The highest total rainfall received was approximately $200 \mathrm{~mm}$ throughout the season. This was probably due to El Niño effect which was associated with the dry summer season. El Niño is the below normal rainfall phenomenon with above normal temperatures which lead to devastating effect in the farming sector. A $92 \%$ chance of extreme El Niño conditions was predicted to occur in January 2016 (Mpheshea and Landman, 2017). This situation was experienced in many regions of Limpopo Province, including the areas where this study was conducted.

In most of the study areas, soil nitrogen content was generally observed to be low under both moringa trees and the control. The standard or critical soil test values in $\mathrm{mg} / \mathrm{kg}$ reported in the literature are 20-30 $(\mathrm{N}),>15(\mathrm{P}), 80-200(\mathrm{~K}),>2000(\mathrm{Ca}),>80(\mathrm{Mg})$, $>5(\mathrm{Fe}), 3-150(\mathrm{Zn})$ and 50-1000 (Mn) (Havlin et al., 2013). Although nitrogen was relatively low, the presence of moringa trees and mainly those over 5 years showed a slightly improved in the nitrogen content in the soil. This improvement might be due to litter fall from moringa leaves. Nitrogen is required by plants for assimilation into protein, and these mainly occur in non-leguminous plant species. Many pasture plants and mature trees derive a large portion of nitrogen from litter and leaf fall (Peverill et al., 1999; Lamb et al., 2014). There are also climatic factors which affect the quantity of soil nitrogen and impact soil organic carbon, which influences soil total nitrogen content. Largely, rainfall and temperature control mineralization, immobilization, denitrification, and leaching of soil nitrogen (Peverill et al., 1999).

Large quantities of plant residues are retained in the soil by many crops, and recycling of nitrogen from these residues may add a large portion of nitrogen to the soil for the benefit of the subsequent crop. This was evident in moringa, whereby younger trees utilized more nitrogen but within the older plants, the nitrogen concentration was relatively higher especially in the clay-dominated soils. Soils in this study were generally low in nitrogen content, however, on relative terms; the $\mathrm{N}$ content of the soils under moringa canopy was slightly higher. The slight increase could be due to low rainfall that affected the decomposition of organic matter in some moringa production areas. Similarly, soil phosphorus concentration was generally low but an increase of $65 \%$ was observed under moringa tree species as compared to the control. From the current study, phosphorus was below the recommended rate of more than 10-20 mg/kg (Peverill et al., 1999; Havlin et al., 2013), in some locations.

Results from the current study showed that potassium and calcium were not limiting nutrients for plant growth in all the study locations. The recommended soil potassium and calcium are reported to be $120-200 \mathrm{mg} / \mathrm{kg}$ and $600-4000 \mathrm{mg} / \mathrm{kg}$ (Peverill et al., 1999). Calcium concentration increases when the soil $\mathrm{pH}$ becomes neutral or alkaline. Furthermore, an increase in potassium by $71 \%$ was observed under moringa canopy as compared to the control across all locations. These results are in agreement with findings by Singh et al. (2012) who reported highest available phosphorus, potassium and calcium under plantations of Ber (Ziziphus mauritiana Lamk), moringa (Moringa olerifera Lam), Karonda (Carissa congesta Wt.) and Khejri (Prosopis cineraria L. Druce) tree species as compared to control soil. The presence of root hairs increases the absorption of $\mathrm{P}$ in many plant species and also deeper root system which could absorb the nutrients at some depth and deposited at the surface. 
Furthermore, it is reported that most terrestrial plants have a symbiosis with arbuscular mycorrhizal (AM) fungi and such colonization has been reported in moringa, where it increases the surface area for P absorption (Peverill et al., 1999; Yamato et al., 2009; Cosme et al., 2014). On the other hand, the fungus has the ability to absorb P from soil solutions with very low $\mathrm{P}$ concentration, thus effectively supplementing the amount of accessible phosphorus to the plant root system (Peverill et al., 1999). The presence of AM fungi mainly in areas with low soil moisture assists in alleviating the problems of reduced mineralization, poor uptake of nutrients and failure of the crop (Muthukumar et al., 2006; Yamato et al., 2009).

Soil $\mathrm{pH}$ under moringa canopy was variable, ranging from moderate to slightly acidic as well as slightly to moderately alkaline, all of which favour the growth of moringa plant. Generally, the $\mathrm{pH}$ was also slightly improved under moringa trees as compared to the control. A soil pH range of 5.0-6.5 is reported to be optimal for growth of most crop species as it increases the availability of calcium element until a $\mathrm{pH}$ concentration of 8 (Peverill et al., 1999). From the current study soils under moringa had a good $\mathrm{pH}$ level which does not affect nutrient uptake by the tree. Litterfall in moringa assists in $\mathrm{pH}$ balancing for ease of nutrient uptake (Singh et al., 2012; Dunsin and Odeghe, 2015).

Over 52 percent of the locations under moringa canopy had a satisfactorily organic carbon content which was above 1 percent at the upper 0-30 $\mathrm{cm}$ depth as compared to the control. A commendable increase was observed from the trees that were more than 5 years old and with high soil clay content (Table 2). According to Peverill et al. (1999), under relatively low rainfall condition and for soils intended for crop production, soil organic carbon is classified to be low, normal and high when the value is $<0.9 \%, 0.9$ to $1.45 \%$ and $>1.45 \%$, respectively. When the field is intended for pasture production, the values are considered to be low, normal and high when they are $<1.74 \% ; 1.74$ to $2.62 \%$ and $>2.62 \%$. Typically, the amount of organic carbon is reduced with increasing soil depth. Similar results were reported by Peverill et al. (1999), who indicated that soil organic carbon is higher at the soil surface and decreases exponentially with depth.

At all locations where data was collected, farmers rely on rainfall for crop water needs. During the study period, many locations of the Limpopo Province experienced drought which affected the production of agricultural crops. During the study, it was found that the rainfall was less than $210 \mathrm{~mm}$ with a maximum temperature of above $30^{\circ} \mathrm{C}$ at all locations (Fig. 1). This might have affected nutrient uptake mainly in soils with a high percentage of sand due to high infiltration rate. The soils which are low in potassium are likely to be light textured in the areas receiving high rainfall of more than $600 \mathrm{~mm}$ annually (Singh et al., 2012).

The low rainfall received during the study period might have also affected microbial activities and led to slow release of nutrients by the plants. The change in organic carbon\% was mainly observed from locations where the soil had some clay in their textural classes, displayed reasonable water holding capacity and the trees were more than 5 years of age. Singh et al. (2012) reported that favourable soil and moisture condition improved the organic carbon of moringa by up to $0.13 \%$ compared to control soil with an organic carbon content of $0.04 \%$. Under conditions where warm temperatures prevail, there is a decrease in soil organic carbon due to increased decomposition rate by soil microorganisms (USDA-NRCS, 2009).

Peverill et al. (1999) further reported that factors such as topography, climatic conditions, soil texture and moisture content affect the amount of organic carbon present in the soil. Usually, a steep slope has higher soil organic matter content because of the 
deposition of organic debris that dominates in clay soils, wetter environments, and finely textured soils. Soil organic carbon serves as the energy source for soil micro-organisms and therefore improves the stability of the soil aggregates. In general soil organic carbon is considered to be low, moderate and high for various soil textural classes. For example, values for different soil types are as follows: sand $(<0.5,0.5-1$ and $>1 \%)$, sandy loam $(<0.7,0.7-1.4$ and $>1.4 \%)$, clay loam or clay $(<1.2,1.2-2$ and $>2 \%)$; these findings were reported by Peverill et al. (1999). The higher gravimetric soil moisture under moringa canopies relative to the control in some of the study locations might be due to litter fall, which covered the soil and possibly reduced the rate of evaporation. However, gravimetric soil moisture was relatively low; this might be due to drought and scanty rainfall received during the season. These findings are in par with Yamato et al. (2009), who reported a soil water content of less than 5\%, although the study was conducted during the rainy season. This was attributed to high temperature which accelerated drought.

No significant differences were found when correlating moringa leaf powder nutritional content and soil properties. The non-significant results on leaf nutritional composition found in this study agrees with the general findings that moringa can be produced under adverse environmental conditions without compromising the leaf nutritional quality. Studies by Anwar et al. (2007) and Kumssa et al. (2017) reported similar findings showing that moringa grows well under different conditions such as the humid tropics or hot dry environments as well as low fertility environments. The tree also survives in less fertile soils and is rarely affected by drought (Morton, 1991; Anwar et al., 2007). A study by Lamidi et al. (2017), reported that crude protein was not significantly influenced by harvesting locations ranging from 23.9 to $27.6 \%$. Another study revealed that agro-ecological conditions have no significant effect on the level of moringa leaf nutrients (Asante et al., 2014).

The study that was conducted evaluating eleven leaf samples of moringa from various locations in Thailand reported protein content ranging between 19.15-28.80 (Jongrungruangchok et al., 2010), which was relatively low as compared to protein content found in leaves used in the current study which ranged between $26.38-33.20 \%$. Higher concentration of $\mathrm{Ca}$ and $\mathrm{Mg}(3.65$ and $0.75 \mathrm{mg} / \mathrm{mL})$ were reported by Anjorin et al. (2010), however, in contrary, their study showed that mineral content in moringa leaves differed significantly with locations.

The concentrated amount of nitrogen, calcium, and phosphorus in the leaves are sufficient, rendering the leaf as a suitable material to be considered in biofertilizer production for soil fertility management and improved crop production (Adiaha, 2017; Mokgophi, 2017). The green leaves are nutritionally rich and can be used as green manure for soil fertility improvement (Mridha, 2015). Moringa leaves can serve as an alternative source of organic matter and calcium or replacement of expensive inorganic fertilizers which majority of smallholder farmers are unable to afford, including facilitating of soil $\mathrm{pH}$ and nutrients release for subsequent plant growth (Undie et al., 2013). The leaves improve soil concentration of N, K, Ca and organic carbon (Undie et al., 2013; Adiaha, 2017). A study conducted under two agro ecological conditions of South Africa also revealed that dried moringa leaves assist to concentrate the high nutrient content of moringa leaves (Moyo et al., 2011), as such it can be used during the time of drought when there is scarcity of food (Thurber and Fahey, 2009; Lamidi et al., 2017). Pakade et al. (2013) recommended that the high levels of trace elements found in moringa are safe 
for human consumption and the leaves contain a substantial amount of flavonols which make the tree to be a natural antioxidant.

\section{Conclusion}

This study revealed that moringa can grow under soils with diverse textural classes. The tree showed a capability to recycle soil nutrients and improve soil fertility. Soil phosphorus was found to increase under older trees, indicating the potential of moringa to enhance phosphorus nutrition on marginal soils. In general, under many instances, improvement in soil $\mathrm{pH}$ and other soil nutrient elements such as calcium and potassium was observed across the study locations. Also, soil organic carbon showed slight increase mainly under older trees. Under the situation where a large portion of the leaves are not harvested for processing, the leaves are allowed to drop on the soil surface and decompose to improve soil structure and mineral elements. This was predominant in soils with high clay content and with older trees that are more than three years of age. Moringa has the potential to contribute towards human and livestock dietary needs and foster rural development, due to its considerable benefits. It is therefore recommended that, the tree should be introduced to other parts of South Africa, for reduction of malnutrition to the vulnerable communities.

Acknowledgements. This project was funded by NRF-Thuthuka; NRF-RVSC; VLIR-IUC-University of Limpopo. To the farmers who grow moringa in the Limpopo Province for allowing samples collection in their fields.

\section{REFERENCES}

[1] Adiaha, M. S. (2017): Potential of Moringa oleifera as a nutrient-agent for biofertilizer production. - World News of Natural Sciences 10: 101-104.

[2] Amaglo, N. (2006): How to Produce Moringa Leaves Efficiently? - In: Workshop on Moringa and other highly nutritious plant resources: Strategies, standards, and markets for a better impact on nutrition in Africa (Vol. 2). Accra, Ghana, November 16-18.

[3] Anjorin, T. S., Ikokoh, P., Okolo, S. (2010): Mineral composition of Moringa oleifera leaves, pods, and seeds from two regions in Abuja, Nigeria. - International Journal of Agriculture and Biology 12: 431-434.

[4] Anwar, F., Latif, S., Ashraf, M., Gilani, A. H. (2007): Moringa oleifera: a food plant with multiple medicinal uses. - Phytotherapy Research 21: 17-25.

[5] AOAC. (1990): Official Methods of Analysis. Association of Official Analytical Chemists. $-15^{\text {th }}$ edition, Helrick, K. (ed.), Arlington.

[6] Asante, W. J., Nasare, I. L., Tom-Dery, D., Ochire-Boadu, K., Kentil, K. B. (2014): Nutrient composition of Moringa oleifera leaves from two agro-ecological zones in Ghana. - African Journal of Plant Science 8: 65-71.

[7] Ashfaq, M., Basra, S. M., Ashfaq, U. (2012): Moringa: A miracle plant for agro-forestry. - Journal of Agriculture and Social Sciences 8: 115-122.

[8] Black, C. A. (1965): Methods of Soil Analysis. Part 1 Physical and mineralogical properties. - American Society of Agronomy, Madison, Wisconsin, USA.

[9] Cosme, M., Franken, P., Mewis, I., Baldermann, S., Wurst, S. (2014): Arbuscular mycorrhizal fungi affect glucosinolate and mineral element composition in leaves of Moringa oleifera. - Mycorrhiza 24: 565-570. 
[10] Dunsin, O., Odeghe, T. O. (2015): Response of sweet bell pepper to moringa leaf extract and organo-bio degradable fertilizer. - Asian Journal of Agriculture and Biology 3: 117123.

[11] Fahey, J. W. (2005): Moringa oleifera: A review of the medical evidence for its nutritional, therapeutic, and prophylactic properties. Part 1. - Trees for Life Journal 1: 5.

[12] Gaines, T. P., Mitchell, G. A. (1979): Boron determination in plant tissue by the azomethine H method. - Communications in Soil Science and Plant Analysis 10: 1099-1108.

[13] Gandji, K., Chadare, F. J., Idohou, R., Salako, V. K., Assogbadjo, A. E., Kakaï, R. G. (2018): Status and utilization of Moringa oleifera Lam: A review. - African Crop Science Journal 26: 137-156.

[14] Havlin, J. L., Tisdale, S. L., Nelson, W. L., Beaton, J. D. (2013): Soil fertility and fertilisers. $-8^{\text {th }}$ ed. Upper Saddle River, Prentice Hall, 528.

[15] Jongrungruangchok, S., Bunrathep, S., Songsak, T. (2010): Nutrients and minerals content of eleven different samples of Moringa oleifera cultivated in Thailand. - Journal of Health Research 24: 123-127.

[16] Kumssa, D. B., Joy, E. J., Young, S. D., Odee, D. W., Ander, E. L., Magare, C., Gitu, J., Broadley, M. R. (2017): Challenges and opportunities for moringa growers in southern Ethiopia and Kenya. - PloS one 12: e0187651.

[17] Lamb, J. A., Fernandez, F. G., Kaiser, D. E. (2014): Understanding nitrogen in soils. University of Minnesota Extension (Revised), pp. 1-5.

[18] Lamidi, W. A., Murtadha, M. A., Ojo, D. O. (2017): Effects of planting locations on the proximate compositions of Moringa oleifera leaves. - Journal of Applied Sciences and Environmental Management 21:331-338.

[19] Lekgau, J. (2011): Moringa oleifera: A Tree Giving Life to Rural Communities. - National Agricultural Marketing Council, USA.

[20] Leone, A., Spada, A., Battezzati, A., Schiraldi, A., Aristil, J., Bertoli, S. (2016): Moringa oleifera seeds and oil: characteristics and uses for human health. - International journal of Molecular Sciences 17: 2141.

[21] Mabapa, M. P., Ayisi, K. K., Mariga, I. K., Mohlabi, R. C., Chuene, R. S. (2017): Production and utilization of moringa by farmers in Limpopo Province, South Africa. International Journal of Agricultural Research 12: 160-171.

[22] Manson, A. D., Roberts, V. G. (2000): Analytical Methods Used by the Soil Fertility and Analytical Services Section. - KZN Agri-Report No. N/A/2001/04. KwaZulu-Natal Department of Agriculture and Environmental Affairs, Pietermaritzburg, South Africa.

[23] Mokgophi, M. M. (2017): Characterisation of vermicomposts and leachate of agroforestry species: Chamaecytisus tagasaste, Moringa oleifera and Vachellia karroo and their potential as soil fertility amendment. - MSc Dissertation, University of Limpopo, 43p.

[24] Morton, J. F. (1991): The horseradish tree, Moringa pterygosperma (Moringaceae) - A boon to arid lands? - Economic Botany 45: 318-333.

[25] Moyo, B., Masika, P. J., Hugo, A., Muchenje, V. (2011): Nutritional characterization of Moringa oleifera Lam leaves. - African Journal of Biotechnology 10: 12925-12933.

[26] Mpheshea, L. E., Landman, W. A. (2016): Predicting the extreme 2015/16 El Niño event. - available at: www.researchspace.csir.co.za.

[27] Mridha, M. A. U. (2015): Prospects of moringa cultivation in Saudi Arabia. - Journal of Applied Environmental and Biological Sciences 5: 39-46.

[28] Muthukumar, T., Senthilkumar, M., Rajangam, M., Udaiyan, K. (2006): Arbuscular mycorrhizal morphology and dark septate fungal associations in medicinal and aromatic plants of Western Ghats, Southern India. - Mycorrhiza 17: 11-24.

[29] Odee, D. (1998): Forest biotechnology research in drylands of Kenya: The development of Moringa species. - Dryland Biodiversity 2: 7-8.

[30] Oshunsanya, S. O., Fagbenro, J. A., Oyewo, T. O. (2015): Growth and mineral composition of Moringa oleifera seedlings as affected by soil texture under water stress conditions. Journal of Applied Agricultural Research 7: 151-160. 
[31] Pakade, V., Cukrowska, E., Chimuka, L. (2013): Metal and flavonol contents of Moringa oleifera grown in South Africa. - South African Journal of Science 109: 01-07.

[32] Peverill, K. I., Sparrow, L. A., Reuter, D. J. (1999): Soil analysis: an interpretation manual. - CSIRO publishing, Collingwood, Victoria. Australia. ISBN 0643063765.

[33] Saini, R. K., Sivanesan, I., Keum, Y. S. (2016): Phytochemicals of Moringa oleifera: A review of their nutritional, therapeutic and industrial significance. - Biotechnology 6: 203.

[34] Singh, I. S., Awasthi, O. P., Singh, R. S., More, T. A., Meena, S. R. (2012): Changes in soil properties under tree species. - Indian Journal of Agricultural Sciences 82: 146-151.

[35] Thurber, M. D., Fahey, J. W. (2009): Adoption of Moringa oleifera to combat undernutrition viewed through the lens of the "Diffusion of Innovations" theory. - Ecology of Food and Nutrition 48: 212-225.

[36] Tshiala, F. M., Olwoch, J. M., Engelbrecht, F. A. (2011): Analysis of temperature trends over Limpopo Province, South Africa. - Journal of Geography and Geology 3: 13-19.

[37] Undie, U. L., Kekong, M. A., Ojikpong, T. (2013): Moringa (Moringa oleifera Lam.) leaves effect on soil $\mathrm{pH}$ and garden egg (Solanum aethiopicum L.) yield in two Nigeria agro-ecologies. - European Journal of Agriculture and Forestry Research 1: 17-25.

[38] USDA-Natural Resources Conservation Service. (2009): Soil Quality Indicators: Total organic carbon. - available at: https://www.nrcs.usda.gov.

[39] Yamato, M., Ikeda, S., Iwase, K. (2009): Community of arbuscular mycorrhizal fungi in drought-resistant plants, moringa spp., in semiarid regions in Madagascar and Uganda. Mycoscience 50: 100-105. 